\title{
Parental Liability for Externalities of Subsidiaries
}

\author{
Domestic and Extraterritorial Approaches
}

\author{
Linn Anker-Sørensen*
}

\section{Introduction}

The significance of corporate groups continues to increase, as well as their economic and political power. ${ }^{1}$ The commercial world, as described by Hadden, "is now dominated both nationally and internationally by complex groups of companies", leaving the significance of the individual company as an outdated illusion that lost its importance in the 1920 s and 1930 s. $^{2}$ So-called subsidiarization is an effective corporate tool for parent companies to externalize the risk of, for example, tort liability through legally separate subsidiaries, though they derive profit from the very activities that generate the risk. ${ }^{3}$ This issue comes to head when we address negative externalities. ${ }^{4}$ The potential separateness between profit and risk has its origin in the extension of the corporate privileges of separate legal entities and limited liability from the individual company to also cover complex webs of companies constituting groups. The overarching question in the following is whether tort creditors, regardless of the corporate privileges, can have a standing in a lawsuit against a parent corporation for negative externalities of subsidiaries.

The methodology used in this paper is comparative and based on examples from 24 jurisdictions. The chosen jurisdictions and their regulatory frameworks are to a great extent based on mapping papers provided in the

* Research assistant in the Research Group Companies, Markets, Society and the Environment and its Sustainable Companies Project, Faculty of Law, University of Oslo (jus.uio.no/companies under Projects). I am grateful to Beate Sjåfjell, Jukka Mähönen, Yuri Biondi and Janet Dine for insightful comments and questions that have improved the legal analysis significantly and to Tineke Lambooy for initial discussions on some of the issues raised in this paper.

1. Černič 2008, p. 71; Blumberg 2001, p. 297; Blumberg 2005, p. 608

Hadden 1984, p. 271.

3. The law suits in connection with asbestos mines and cigarette manufacturers are typical examples of shielding other affiliated companies from potential tort liability by subsidiarization; cf. Antunes 1994; Dearborn 2009, pp. 197-198.

4. In economics, a negative externality is the cost that affects a party who did not choose to incur that cost; see Buchanan \& Craig Stubblebine 1962; Johnston 2012, p. 1.

international Sustainable Companies Project. ${ }^{5}$ The analysis of parental liability regulation does not aim at an indepth comparative analysis, but rather to illustrate potential paths that are accessible in various jurisdictions to hold a parent company liable for their subsidiaries' externalities. ${ }^{6}$ This can bring clarity to the variety of liability schemes and also contribute some ideas about what constitutes a sufficient solution to this global concern.

The main findings of this paper is that various liability schemes can be subdivided into 8 different categories of parental liability for externalities of subsidiaries. However, there appears to be constraints within all the categories in order for the plaintiff to be successfully compensated. The most important constraint that apply to all of the regulatory and judicial paths of parental liability is that the burden of proof rests on the plaintiff. The main conclusion is that there is a need of a shift in the burden of proof, and that there is a need of a more functional understanding of corporate groups in order to establish more solid principles and regulations for parental liability of externalities caused by a subsidiary. In section 2, I will start by setting the scene of the understanding of corporate shareholders and legal effects of corporate privileges. In section 3, I will present a structural analytical tool in order to systemize various liability approaches, which also provides the further structure of this paper. In sections 4 and 5, the possibilities and barriers in the domestic context are examined. Domestic regulation rarely covers the extraterritorial aspect where a parent company can be held liable for the conduct of its foreign subsidiaries by the extension of domestic regulations to a foreign dispute, and in sections 6 and 7, I therefore examine how such extraterritorial parental liability can be addressed in both a statutory and a judicial approach. Section 8 summarizes and offers some reflections.

5. For more information, see <www.jus.uio.no/companiesunderProjects $>$ (accessed 6 January 2015).

6. Even though the focus of this paper is on environmental externalities, other negative externalities can serve as an illustration of how these matters can be solved. Human rights offences are one example. 


\section{Setting the Scene: Corporate Shareholders and Corporate Privileges}

Historically, the acceptance in the late 19th century of companies as shareholders, providing the possibility for them to own shares in other companies, gave the legal basis for group structures. ${ }^{7}$ There is no uniform definition of corporate groups, and the concept covers the spectrum from highly centralized to largely diversified groups. ${ }^{8}$ The two main concepts of group establishments are share ownership and control, where the former is more commonly accepted and defined than the latter. ${ }^{9}$ As an example, we find this notion in the definition of multinational groups by the United Nations Conference on Trade and Development (UNCTAD), where a parent company is regarded "an enterprise that controls assets of other entities in countries other than its home country, usually by owning a certain equity capital stake". ${ }^{10}$ A weakness with share ownership as a decisive factor for a group definition is that it is formalistic and can easily be manipulated by clever consultants. ${ }^{11}$ Hadden explains the adoption of an equitybased group definition by the lawyers' need of a formalistic concept "for the purposes of the production of consolidated accounts, and the implementation of their taxation regimes". ${ }^{12}$ However, as evident from, for example, the EU's Accounting Directive, accounting law has extended its definition of a parent company to contain not only the formal majority of equity definition but also de facto control that, in turn, can stem from an agreement between companies or individual shareholders. ${ }^{13}$ The underlying rationale is that companies shall report on their factual economic relationships. It can be questioned whether company law lags behind, in this

7. Blumberg et al. 2005, § 3.04; Blumberg 2005, p. 607. In the USA, New Jersey was the first state to allow corporations to own shares in other corporations in 1888, and in Europe, case law dated back to 1879 in France, 1877 in Germany and 1867 in the UK and refers to corporations' ability to own shares; cf. Antunes 1994, pp. 33-36.

8. Vandekerckhove 2007, pp. 17-18.

9. The concept of control can further be subdivided into, e.g. behaviour control and economic control; see Dearborn 2009, pp. 246-251.

10. United Nations Conference on Trade and Development, Transnational corporations (TNC). Available at <http://unctad.org/en/Pages/DIAE/ Transnational-corporations-(TNC).aspx $>$ (accessed 2 September 14).

11. As observed by Dearborn: "Limited liability and veil piercing place excessive focus on corporate formalities, so much so that today's megacorporations with massive legal teams can carefully guard against liability by establishing subsidiaries and maintaining distinct corporate identities"; cf. Dearborn 2009, p. 208.

12. Hadden 1983, p. 2

13. 2013/34/EU of the European Parliament and of the Council of 26 June 2013 on the annual financial statements, consolidated financial statements and related reports of certain types of undertakings, amending Directive 2006/43/EC of the European Parliament and of the Council and repealing Council Directives 78/660/EEC and 83/349/EEC (Text with EEA relevance), replaced the Fourth and Seventh Accounting Directives including the Modernisation Directive. This Directive has to be implemented in national legislation within 20 July 2015. For a crossjurisdictional analysis of accounting standards, see Mähönen \& Villiers 2015. regard, when the most recognized definition of groups in companies acts still solely rests on the percentage of shareholding. A formalistic definition can lead to evasion of liability. Accordingly, the issue of companies as shareholders can be divided into, first, the question of whether share ownership is a sufficient criterion for group establishments and second, the problem that legislators and courts often fail to acknowledge the functional differences that may exist between various types of shareholders. ${ }^{14}$ According to Strasser, this function difference is evident from the various aims of the investments, where the corporate shareholder's aim occasionally is to create, operate and dissolve subsidiaries "primarily as part of a business strategy in pursuit of the business goals of the larger enterprise, which the parent and all the subsidiaries are pursuing together". ${ }^{15}$ The courts' acceptance of corporate shareholders as, in several cases, identical with private investors has in turn led to a parallel acceptance of an extension of the corporate privileges from the private to the corporate shareholder. However, one could ask, are the purposes of the corporate privileges of separate legal entities and limited liability fulfilled in the context of corporate shareholders? According to Strasser and Blumberg, limited investor liability is justified by transactional costs. First, limited liability reduces the cost of monitoring both the solvency of other shareholders and the board's activity out of fear of, for example, involvement in detrimental transactions that, in turn, can cause shareholder liability. Second, and as a result of the former transactional costs, limited liability facilitates investments because of the lack of exposure of the shareholders' "personal assets to a greater risk of liability". ${ }^{16}$ Regarding corporate shareholders, these transactional costs should arguably only serve as a justification for corporate shareholders with portfolio investments. For corporate shareholders, both those constituting parent companies and those who exercise control rights but without the required shareholding to qualify as a parent company, the presumable influence on and information from subsidiaries lead to a lack of justification of limited liability based on the argument of transactional costs. Regarding tort claims, as noted by Dearborn, it seems questionable that "the entity [or entities if more than one company exercise controlling rights together, that are] best able to prevent the worst harms [are] not incentivized to do so, which may foist the costliest harms of corporate conduct onto the public at large". ${ }^{17}$ The potential result of the unjustified extension of limited liability to corporate shareholders exceeds the risks reflected in the transaction costs referred to above. ${ }^{18}$ Further, as introduced by Berle in 1947, the argument can be made that as long as the corporate shareholder is entitled to the potential

14. See, e.g., Strasser \& Blumberg 2009; see also UK decision of Salomon v. Salomon \& Co. Ltd. (1897). For some practical examples, see Werlauff 2008.

15. Strasser 2005, p. 638

16. Strasser \& Blumberg 2009, p. 7.

17. Dearborn 2009, p. 205.

18. Strasser \& Blumberg 2009, p. 8. 
benefits of, for example, lenient environmental regulation, it should also be possible to hold the same corporate shareholder liable for the same activity that he is a beneficiary of. ${ }^{19}$ In this way, Berle addressed the factual differences of corporate and private shareholders, arguing that the fiction of a formal understanding of corporate groups is a potential social-economic costly approach. The corporate liability shield, when extended to the corporate shareholder, only results in a cost on society to pay for the harms caused by risky subsidiaries' conduct, which is "especially expensive when the potential harms are greatest, for example, in industries involving ultrahazardous activities or those that potentially impose large human rights or environmental costs on the public and in areas that lack government safeguards or subsidization". ${ }^{20}$ Berle's solution was to introduce 'enterprise liability' which would impose parental liability whenever the parent company directly profits from a subsidiary's conduct. ${ }^{21}$ This approach has unfortunately not found sufficient support by domestic legislatures, meaning that the corporate shareholder still is equalized with other investors that in some circumstances only hold a minority shareholding by a portfolio investment. In addition to the privilege of limited corporate liability, individual group companies are due to prevailing entity theory regarded as independent legal entities treated separately from its shareholders. ${ }^{22}$ In its strict sense, entity theory has led to an enhanced recognition of the principle of limited liability in common law jurisdictions. ${ }^{23}$ Consequently, the parent company can, as a matter of company law, be held liable only on a very limited scale, mostly based on the scope of veil piercing, that I will return to in section $4 .{ }^{24}$ Civil law jurisdictions have permitted corporate groups to evolve within the

19. Berle 1947

20. Dearborn 2009, p. 200.

21. Berle 1947, p. 344.

22. For use of different terms in this repect, see Biondi et al. 2007, where what is here refered to as entity theory is refered to as legal person theory of the company, and what is here refered to as enterprise theory is refered to as entity theory (as in the firm as an entity).

23. See, e.g., the UK decision of Salomon v. Salomon Co. Ltd. (1897); the court applied the judicial understanding of separate corporate personality that up to that time only had been applied for groups. By result, the court established a general principle in law applicable to all companies; see Strasser \& Blumberg 2009, p. 25. For arguments in favour of limited liability for investor shareholders (as distinct from corporate shareholders), see Strasser \& Blumberg 2009, p. 7. A survey of about 40 jurisdictions all over the world confirms that some form of 'separate personality' and 'limited liability' exists in these surveyed jurisdictions; see Mandate of the Special Representative of the Secretary-General (SRSG) on the Issue of Human Rights and Transnational Corporations and other Business Enterprises, Corporate Law Project (July 2010), 9 (SRSG, Corporate Law Project)

24. Piercing of the corporate veil refers to a situation where the shield of limited liability is disregarded, resulting in an identification between shareholders (or parent company) and the company itself (subsidiary), leaving the shareholders (parent) liable for the company's (subsidiary's) affairs. Various jurisdictions apply various approaches to this doctrine, and some jurisdictions do not apply it at all. It can also be applied in an extraterritorial context, even though this rarely happens. framework of traditional company law, ${ }^{25}$ and thereby have similarly accepted the notion of companies in groups as separate legal entities with full legal capacity. The legal vacuum created by the overall recognition of separate legal entities and limited liability results in an anachronistic overemphasis of companies in groups as single independent companies without due consideration of the factual, often closely interlinked economic relationship that can exist between affiliated companies. ${ }^{26}$ The result, as Blumberg argues, is that parent companies are able to use layers of subsidiaries to effectively insulate themselves from much of the liability that could arise from operating business enterprises. ${ }^{27} \mathrm{With}$ limited shareholder liability for parent companies as the general norm, ${ }^{28}$ the question discussed in this paper is to what extent a parent company can be held liable for environmental harm caused by a subsidiary, in both a domestic and extraterritorial context. The latter refers to cross-jurisdictional liability, in other words, to which extent a foreign parent company can be held liable for its local subsidiaries' environmental externalities. ${ }^{29}$

\section{Various Approaches to Address Parental Liability: A Need for a Structural Analytical Tool as a Basis for Comparative Study}

The need of a change in traditional liability regimes in relation to corporate groups has been referred to as "one of the great unsolved problems of modern company

25. With the important modification of group regulation within tax and accounting law, see, e.g. Seventh Accounting Directive, <http://eur-lex. europa.eu/LexUriServ/LexUriServ.do?uri=CELEX:31983L0349:EN: NOT> (accessed 2 June 2014). Recently amended in 2013, 'Directive 2013/34/EU of the European Parliament and of the Council of 26 June 2013 on the annual financial statements, consolidated financial statements and related reports of certain types of undertakings, amending Directive 2006/43/EC of the European Parliament and of the Council and repealing Council Directives 78/660/EEC and 83/349/EEC (Text with EEA relevance)' replaced the Fourth and Seventh Accounting Directives including the Modernisation Directive. This Directive has to be implemented in national legislation by 2015 . For a cross-jurisdictional analysis of accounting standards, see J. Mähönen \& C. Villiers 2015.

26. See Biondi et al. 2007; Strasser \& Blumberg 2011.

27. Blumberg et al. 2005, ch. 3; Blumberg 2001, p. 303.

28. This is because the general veil piercing doctrine within common law jurisdictions happens "freakishly...[l]ike lightning it is rare, severe, and unprincipled", as noted already by Easterbrook \& Fischel 1985, and in civil law jurisdiction, is often based on either statutory provisions or a concept of 'abuse', as pointed out already by Antunes 1994, pp. 250-258.

29. There exists a wide range of reports documenting severe environmental damage caused by multinational corporations: e.g. United Nations Environmental Programme, Environmental Assessment of Ogoniland Report, <www.unep.org/disastersandconflicts/CountryOperations/ Nigeria/EnvironmentalAssessmentofOgonilandreport/tabid/54419/ Default.aspx.> (accessed 29 September 2014); Sands et al. 2012, pp. 15-16; Redgwell 2014 
law". 30 The unsolved problem is in reality a question of the scope of the doctrine of limited liability. Allowing groups with limited liability is according to Blumberg a 'historical accident' with no "resemblance to the economic reality". ${ }^{31}$ Various theories and soft law sources have been developed in order to limit the effect of the legal vacuum created by a group's corporate privileges. Introduction of the "tailored limited liability" by Millon, ${ }^{32}$ the "floating and flexible" liability scheme by Antunes, 33 the "modern enterprise theory" by Blumberg and Strasser ${ }^{34}$ and the two alternative regimes suggested by Hansmann and Kraakman of "joint and several unlimited liability" or "pro rata unlimited liability" 35 are only some of the theories suggesting an improved regime with a better consideration of the legal and factual circumstances that corporate groups operate within. These theories, advocating a holistic consideration of a group's conduct, are often referred to as the application of enterprise theory - as opposed to entity theory. ${ }^{36}$ Enterprise theory applies "liability according to the patterns of the economic enterprise instead of stopping at the contours of the legal fiction", ${ }^{37}$ accepting that claimants of one actor in a corporate group seek redress from another member of the group, under ordinary tort circumstances. ${ }^{38}$ In addition, international organizations such as the UN and OECD have developed soft law regulations on the behaviour of corporate groups where their liability for externalities is one of the core issues. ${ }^{39}$ Nevertheless, the legal theories and most soft law mechanisms have legal impact only if they are implemented in national law, included in the interpretation of domestic legislation or established through ruling of domestic or international courts. Therefore, in the following, my focus will be on legal mechanisms, and I will distinguish between statutory and judicial approaches. This is in line with the economists' approach to solving negative externalities that, generally, is divided into an instrumental approach (regulate or tax the activity) and a market approach, by leaving the issue to bargaining between the violator and the victim. ${ }^{40}$ Involuntary creditors, such as tort creditors after environmental damage and labour claimants, are not necessarily in a position to contract around limited liability or to bargain for higher compen- sation. ${ }^{41}$ The overarching question in the following is therefore whether parent companies due to legal norms are potentially liable for negative externalities caused by subsidiaries, impacting third parties.

The matrix presented in Figures 1 and 2 can serve as an analytical tool in order to systemize various liability approaches in a comparative perspective. The different layers of the liability model will also serve as the structure of this paper.

The matrix illustrates the complexity and varieties concerning legal regulation of parental liability for their subsidiaries' environmental externalities. First, parental liability for groups with solely domestically affiliated companies is distinguished from parental liability in a cross-jurisdictional context, the latter referred to as extraterritorial liability. However, the extraterritorial liability approach will in most cases stem from an extraterritorial reach of a domestic liability scheme. I will not address potential international standards that could be applied extraterritorial per se, but rather focus on the extraterritorial reach of some liability schemes found in the jurisdictions I have examined. Second, both in a domestic and extraterritorial context, parental liability can be divided into jurisdictions applying a statutory approach and jurisdictions applying a judicial approach. ${ }^{42}$ Statutory approaches may be found notably in company acts and environmental and insolvency legislation. ${ }^{43}$ In contrast, a judicial approach refers notably to the courts assessment and application of the veil piercing doctrine and in an extraterritorial context, an evolving legal trend referred to as foreign direct liability. ${ }^{44}$ Third, both statutory and judicial approaches are divided into a fault-based (indirect) and non-fault-based (direct) parental liability. ${ }^{45}$ In the indirect liability scheme, parental liability can be alleged within the concept of a duty of care, leaving the corporate privileges intact. $^{46}$ In the non-fault-based (direct) liability scheme, the corporate privileges are disregarded (or challenged),
30. Schmitthoff 1982, p. 363

31. Blumberg 1987 and 2000, p. 5; Blumberg 2001, p. 303.

32. Millon 2007, pp. 1360 et seq.

33. Antunes 1994, p. 294.

34. See, e.g., Strasser \& Blumberg 2009.

35. Hansmann \& Kraakman 1991.

36. The rationale behind applying enterprise principles can be understood as protecting third parties affected by the corporate activity or as an initiative towards fulfilment of the statutory objective at hand; see, e.g., Blumberg 2005, p. 611.

37. Dearborn 2009, p. 211

38. Antunes 1994, p. 8.

39. See OECD Guidelines for Multinational Enterprises (2011), part VI, available at <www.oecd.org/daf/inv/mne/48004323.pdf> (accessed 4 June 2014); UN Global Compact, principles 7-9, available at $<w w w$. unglobalcompact.org/AboutTheGC/TheTenPrinciples/environment. html> (accessed 4 June 2014).

40. For a more comprehensive assessment of legal-economic approaches to externalities see Biondi 2011
41. Vandekerckhove 2007, p. 8

42. There are also examples of jurisdictions applying both a statutory and a judicial approach, see, e.g., the intragroup liability schemes in Germany described by Antunes as a 'dualist approach'; see Antunes 1994.

43. For certain behaviour, criminal law also addresses environmental liability, but this will not be touched upon in the following; see, e.g., report from IMPEL Networks, 'Criminal Enforcement of Environmental Law in the European Union' (2000), available at <http://impel.eu/wp-content/ uploads/2010/02/2000-04-criminal-enforcement-FINAL-REPORT.pdf> (accessed 12 June 2014).

44. Foreign direct liability claims are based on tort law and principles paving the way for a potentially new form of judicial liability.

45. By contrast to this terminology, in international law, a direct liability often refers to a corporate liability distinguished from an indirect liability scheme where states are the addressees; see Hamilton 1989, pp. 72-92.

46. Since it is based on a wrongful act made by the parent, no exception to the limited liability and separate legal personality is needed. 
Figure $1 \quad$ Liability matrix by Linn Anker-Sorensen (part 1)

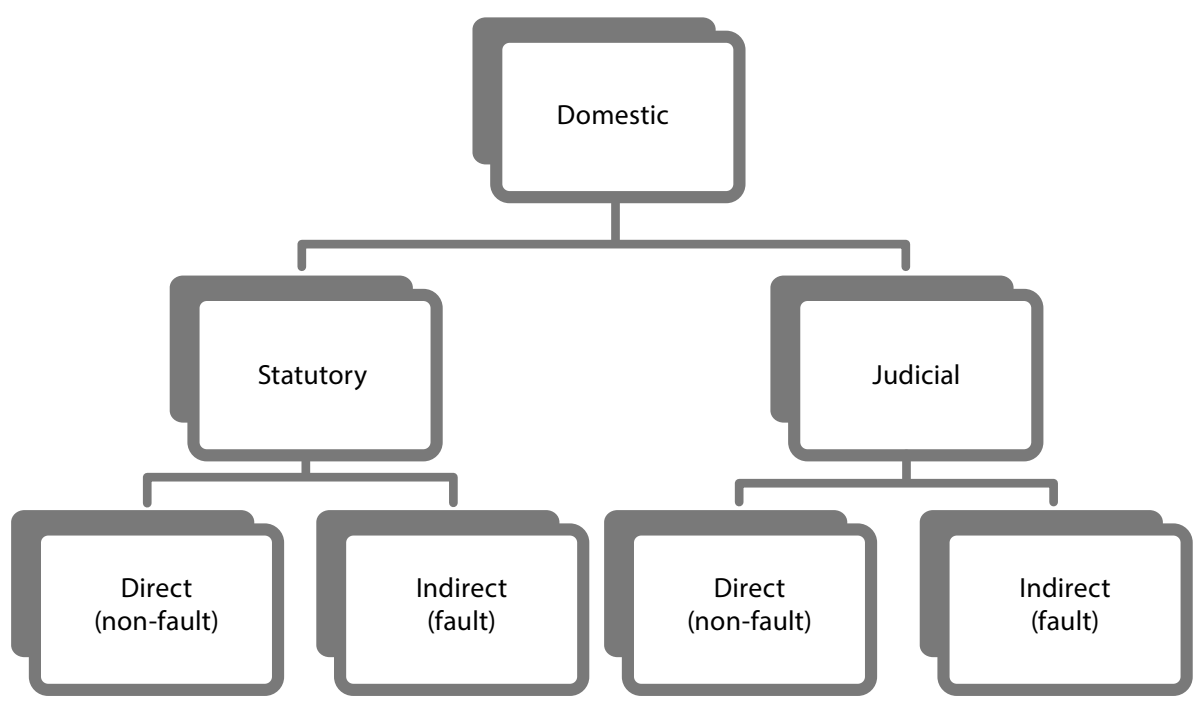

Figure 2 Liability matrix by Linn Anker-Sorensen (part 2)

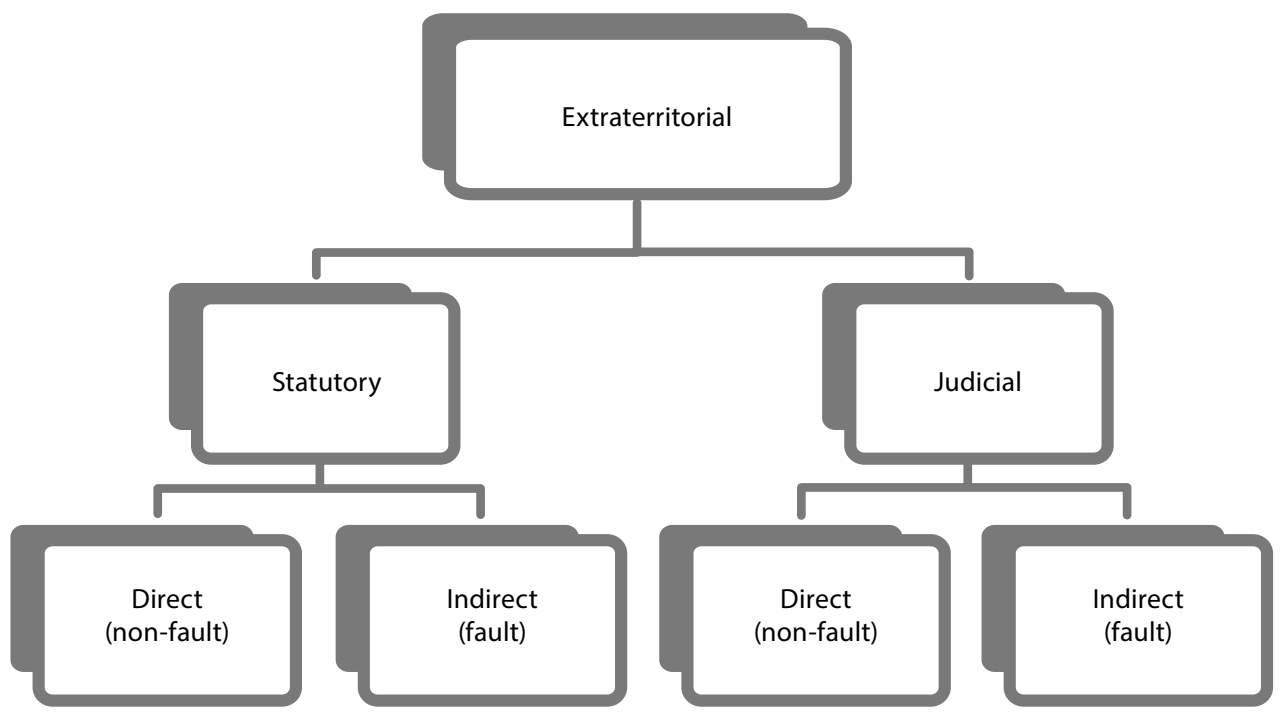

and liability can be invoked by a formal parent-subsidiary relationship. ${ }^{47}$

I will now describe each of the liability varieties mentioned in the matrix and give examples of where to find them.

47. Jurisdictions applying a strict notion of the entity principle do not recognize so-called direct piercing of the corporate veil. This is evident in, e.g., the UK based on the court's decision in the 'unyielding rock' (Lord Neuberger) of company law by Salomon v. Salomon \& Co. Ltd. (1897), AC 22; the USA, see Taylor 2012, sect. 6.1; Australia, see Deva 2013, sect. VI, C; and South Africa, see Henning, du Plessis \& Koorsen 2012, sect. 6 .

\section{Domestic Statutory Parental Liability: Corporate Groups Regulations}

\subsection{Company Law}

In the domestic context, statutory approaches are found in quite a few jurisdictions. The German Konzernrecht (1965) is normally understood to present the most sophisticated legislation on group liability, containing explicit standards for parental liability. ${ }^{48}$ It has also influenced the group legislation of Brazil (1976), ${ }^{49}$ Por- 
tugal (1986), ${ }^{50}$ Hungary (1988), ${ }^{51}$ Slovenia (1993), ${ }^{52}$ Albania $(2008)^{53}$ and Turkey (2012). ${ }^{54}$ Due to the status of the German regulation of corporate groups, I will start by examining the various liability schemes incorporated in the German Stock Corporation Act (GSCA), which codifies the Konzernrecht, and include examples from other jurisdictions to illustrate nuances in the indirect and direct liability approaches. Important in this regard is that the statutory liability approach mainly poses a duty for the parent to compensate the subsidiary, but not necessarily third parties such as tort creditors. Such internal and intragroup liability schemes will only take consideration of tort creditors after they have succeeded in achieving a claim against the tortfeasor (subsidiary), which, in turn, provides them with a legal claim against the subsidiary that can be considered part of that particular subsidiary's debt. ${ }^{55}$ Thereby, the main difference between statutory regimes where parent companies owe a duty to compensate subsidiary's debt and a parental duty to compensate tort creditors of the subsidiary is the time perspective. In several jurisdictions, parental liability is only reflected by compensation of a subsidiary's debt. This, however, does not mean that tort creditors are excluded, but that such statutory regimes provides an additional barrier for the tort creditors - first having to be successful in achieving a claim against the subsidiary for a particular conduct and then succeeding in providing proofs of detrimental parental actions that caused the incident the tort creditor's claims stem from. Therefore, in the following, we regard the statutory liability schemes only referring to compensation of debt as a slow and expensive route for externality-liability, and we are especially interested in statutory approaches where also other creditors are within the scope of parental liability.

Domestic statutory liability schemes can be divided into an indirect and direct parental liability for externalities of subsidiaries. The statutory indirect liability scheme is recognized by a detrimental transaction or conduct of the parent company that has caused a detrimental action by the subsidiary, and the applicable law provides a compensation scheme in the parent-subsidiary relationship. By contrast, the direct parental liability is recog-

48. 'Aktiengesetz' of 1965; for contractual groups in Germany, see AktG $\S 302(1)$, translated in Schneider \& Heidenhain 2000, pp. 275-276. For de facto groups in Germany, see AktC §§ 311(1) and 317(1), translated in Schneider \& Heidenhain 2000, pp. 287, 293-294; see Reich-Graefe 2005, p. 791. This liability scheme only addresses the parent company shareholders in stock corporations and not the individual investor shareholder. For groups containing private limited liability companies $(\mathrm{GmbH})$, the court tend to analogize the $\mathrm{GmbH}$ to the AG in order to apply the GSCA, which codifies the Konzernrecht; cf. the case Autokran, Bundesgerichtshof (BGH) 9 September 1985, 95 Entscheidungen des Bundesgerichtshofes in Zivilsachen (BGHZ) 330 (F.R.G.). I will return to the significance of this analogical interpretation for private limited liability companies in Germany below in sect. 4 .

49. Vizziotti et al. 2012

50. 'Còdigo das Sociedades Comerciais' of 1986, Art. 501; see Antunes 2008, p. 29.

51. Art. 56 (3) (c) of the Companies Act for the recognized group, and Art. 64(1)-(4) for the de facto group, referred to in Nikolicza 2013, pp. 589-591. nized by liability based on a formal parent-subsidiary relationship, without a criterion of culpability or negligence by the parent. In Germany, we find both categories of statutory liability, depending on whether the group has concluded a contract formalizing the parentsubsidiary relationship, the factual versus contractual group. Whereas the former applies a statutory indirect liability, the latter applies a direct liability approach. ${ }^{56}$

As already mentioned, the German Konzernrecht is normally understood to represent the most sophisticated domestic statutory liability scheme, providing a general parental liability for 'members of a group of companies' in both a factual and a contractual group. This intragroup liability is based on the assumption of the entire group as under a "common direction of the controlling enterprise", ${ }^{57}$ which, in turn, provides a legal obligation of parental compensation for losses suffered by a subsidiary, based on a presumption of parental direction.

In de facto groups, the parent can only be held liable on a case-by-case basis where the claimant succeeds in providing proof of a detrimental parental interference and a causation link between this interference and the damages or losses sustained by the subsidiary, providing a statutory indirect liability scheme. ${ }^{58}$

Similarly, in Lithuania ${ }^{59}$ and Norway, ${ }^{60}$ a causal link between an unfair shareholder action and the subsidiary's inability to fulfil its obligations is necessary to conclude parental liability. A domestic variation seems to be the content of the criteria for a causal link. For example, in Germany, the claimant would have to prove the precise parental conduct or instruction that constituted the detrimental action by the subsidiary, providing a strict burden of proof. Similarly, in the Norwegian Companies Act, the statutory indirect liability scheme stems from traditional culpability of the parent. In contrast to

52. Art. 8 Companies Act provides the general criteria of veil piercing, and Arts. 543 and 547 of the Companies Act provide special provisions of veil piercing for environmental damages within a group context, see Zrilič 2012, p. 38.

53. Art. 207 et seq. of the Law No. 9901 on Entrepreneurs and Companies 2008; see, e.g., Bachner, Schuster \& Winner 2009.

54. Art. 195-209 of the New Turkish Commercial Code; see, e.g., Eroglu 2013, Part C.

55. Dearborn 2009, p. 218 and text in footnote 131. Similarly, in e.g. Brazil, where the Lei das Sociedades Anònimas Art. 246 makes the controlling corporation liable for abuse of power and Art. 245 prohibits conflict of interest (and fiduciary duties) between the dominant corporation and the subsidiary; cf. Antunes 1994, pp. 325-326; see, e.g., Sjåfjell 2009; Biondi 2014.

56. See AktG §§ 311(1) and 317(1), translated in Schneider \& Heidenhain 2000, pp. 287, 293-294.

57. German Stock Corporation Act $\S 18$, para 1. So-called members of a group of companies are considered the 'most important subcategory of affiliated enterprises' in Germany; cf. Wirth \& Arnold 2004, p. 185; Schneider \& Heidenhain 2000, p. 17.

58. Reich-Graefe 2005, pp. 791-792. Procedurally, on the one hand, it is nearly impossible to prove such a detrimental interference by the parent, when on the other hand, a de facto concern is often characterized by 'highly interconnected companies with a multitude of parental interference'.

59. Art. 2.50(3) of the Civil Code; UAB 'Göllner spedition' v. S. B. ir kt. [2004] No. 3K-3-124/2004 (Supreme Court of Lithuania), cited in Lauraityte \& Miliauskas 2013, sect. 7.1.

60. Art. 17 of the Public and Private Companies Act; see Sjåfjell 2013, sect. 4.1.1. 
the indirect liability scheme in Germany and Norway, the Lithuanian Supreme Court has held that the actual role and possibility to influence the activity of the subsidiary are the core criteria to disregard corporate privileges, providing the grounds for a potentially broad parental liability approach. ${ }^{61}$

An alternative broad liability approach can be found in jurisdictions like China, ${ }^{62}$ Macedonia $^{63}$ and Ghana, ${ }^{64}$ grounding the concept of veil piercing within company law but leaving the further interpretation of the concept to the courts. An innovative and potentially broad statutory indirect liability approach can be found in the Albanian Entrepreneurs and Companies Act introducing an environmental duty of care. ${ }^{65}$ This approach can invoke liability where directors have failed to take decisions in the best interest of the company as a whole, paying "particular attention to the impact of its operation on the environment". 66 Thereby, as argued by Dine, the potential liability that stems from directors' fiduciary duties could facilitate parental liability towards tort creditors in a subsidiary, through the court's ability to "consider all the aspects of a business decision, including the long-term advantages of a group decision even if measured against short-term disadvantages - factors likely to influence the decisions of the independent directors of subsidiary companies, who cannot but respect their company's embeddedness in the group". ${ }^{67}$ A statutory direct liability scheme applies for German contractual groups. These are recognized by their control agreements leaving the parent companies with farreaching control over the subsidiaries' operations, ${ }^{68}$ with an equally far-reaching parental liability. The liability of contractual groups does not stem from company law principles, but rather as a potential consequence of concluding a control agreement. ${ }^{69}$ As described by ReichGraefe, "the German stock corporation law applies a contractual response - a hybrid form of 'statutory-contractual' quid pro quo - which obliterates the parent company's limited liability as the contractual counterparty of its controlled subsidiary". ${ }^{70}$ This results in a statutory direct liability scheme where the parent can be held liable even without any wrongdoings, leaving the

61. Lauraityte \& Miliauskas 2013 , sect. 7.1 .3 ; shareholding of only $25 \%$ of the voting rights can be enough to establish shareholder liability under specific circumstances.

62. Art. 20 in the Company Law of 2006 introduced the concept of veil piercing in Chinese company law; see Lou \& Tian 2013, sect. 7.1.

63. Art. 28 Companies Act provides general criteria for veil piercing; see Stamenkova van Rumpt 2011, sect. 6.1 and sect. 7.

64. GCC s 38; s 121(1)-(4), see Schwartz 2013, sect. 6.3

65. Art. 98 in Law No. 9901 On Entrepreneurs and Companies 2008.

66. Arts. 98 and 209(2) in Law No. 9901 On Entrepreneurs and Companies 2008.

67. Dine 2012, p. 68

68. See AktG § 291(1), translated in Schneider \& Heidenhain 2000, p. 265; Reich-Graefe 2005, p. 789; The only two limits of this parental control are that it is exercised within the best interest of the group as a whole and that it does not render the subsidiary insolvent.

69. Reich-Graefe 2005, p. 789.

70. Ibid., p. 789. parent company to compensate the subsidiary's annual deficits during the contract period..$^{71}$

Inspired by the German Konzernrecht, a similar statutory direct liability scheme can be found in Portugal, where the Código das Sociedades Comerciais recognizes a broad parental right to direct the conduct of the subsidiary, ${ }^{72}$ a parallel parental liability for covering the annual losses of the subsidiary," ${ }^{73}$ and "a direct joint liability before subsidiary creditors for the settlement of unpaid debts". ${ }^{74}$ Both the above-described German and Portuguese statutory direct liability schemes reflect the internal group relationship, narrowed to a parental duty to compensate for the subsidiary's debt. In Germany, other creditors are only considered whenever a so-called integration agreement is concluded in the parent-subsidiary relationship. ${ }^{75}$ An integration agreement provides the parent with even more extensive rights than under conclusion of an ordinary contractual group, meaning that the parent can order the subsidiary to conclude a detrimental transaction or also potentially to endanger the existence of the subsidiary. ${ }^{76}$ This approach seems to be in line with the stringent and severe liability scheme of the French proposal in the 1970s, the 'Proposition Cousté'. This proposal advocated a joint and several liability scheme for the parent company, based on a legal presumption of the existence of dominant influence when a company holds as little as 25 per cent or more of the voting capital. ${ }^{77}$ Based on the presumption of dominant influence, creditors of the subsidiary could choose to bring proceedings "either against the subsidiary or the parent (...), irrespective of the event of default of the corporate debtor and even in the case that the debts have not originated from an actual exercise of the parent's control". ${ }^{78}$ The proposal was, however, never formally adopted, leaving French courts to develop, elaborate and refine theories on groups of companies. ${ }^{79}$ The French court's reasoning in cases involving harms caused by the business activities of French companies has led to another proposal for legislation in this respect, aiming at holding French companies liable both home and abroad for environmental and social impacts of businesses. ${ }^{80} \mathrm{I}$ will revisit the new French proposal in section 5 below concerning extraterritorial statutory approaches.

71. See AktG $\S 302(1)$, translated in Schneider \& Heidenhain 2000, pp. 275-276.

72. Código das Sociedades Comerciais Arts. 483 and 503.

73. Código das Sociedades Comerciais Art. 502.

74. Código das Sociedades Comerciais Art. 501; see AktG § 302(1), translated in Schneider \& Heidenhain 2000, p. 326; see also Antunes 2008, p. 29.

75. German Stock Corporation Act §§ 319 and 322.

76. German Stock Corporation Act $\S 323$

77. Proposition de Loi No. 1055 sur les Groupes de Sociètès et la Protection des Actionnaires, du Personnel et des Tiers, Art. 2, referred to in Antunes 1994, pp. 290-291.

78. Antunes 1994, p. 291.

79. See, e.g., Guyon 1993.

80. Proposition de Loi Relative Au Devoir de Vigilance Des Sociètès Mères et Des Entreprises Donneuses D'ordre 1524 (2013), available at <www. assembleenationale.fr/14/pdf/propositions/pion1524.pdf> (accessed 22 September 2014), referred to in Taylor 2014 
The overall focus of intragroup liability within company law provides us with a further question of whether tort creditors are considered within domestic environmental regulation instead. ${ }^{81}$

\subsection{Environmental Law}

Environmental law applies different concepts than traditional company law in order to pin a parent to the mast for environmental damages. Various criteria apply in various jurisdictions, but generally, one can also divide parental liability in environmental law into direct and indirect liability schemes.

A direct liability (or 'strict liability') can be found in, e.g. Finland, ${ }^{82}$ Poland ${ }^{83}$ and Brazil, ${ }^{84}$ aiming at holding a parent liable regardless of culpability. In these jurisdictions, the legal personality may be disregarded whenever harms are caused to the quality of the environment. However, the plaintiff still has to succeed in providing proof of a sufficient connection between the conduct of the company/group and the caused damage. ${ }^{85}$ Mähönen argues that competence, financial relationship and profit possibly gained by the tortious activity are core parameters in the consideration of this parental liability in Finland. ${ }^{86}$ Such criteria indicate a dynamic enterprise approach instead of a solely formalistic parent-subsidiary relationship. This is in line with the general purpose of a strict environmental liability for corporate groups, aiming at seeking compensation for incurred damages by the subsidiary or by the parent company. ${ }^{87} \mathrm{~A}$ direct statutory environmental liability approach can provide compensation of tort creditors.

A connection between the parent and the environmental damage is also a criterion in the indirect liability schemes found in notably Spain ${ }^{88}$ and Sweden. ${ }^{89}$ In

81. Blumberg points out that most enterprise laws do not stem from company, contract and tort law but rather other areas of law; see Blumberg 2005, pp. 610-611.

82. A company's environmental liability is regulated in the Environmental Protection Act, Act on Compensation for Environmental Damage and Environmental Damage Insurance Act. The direct environmental liability is found in $\S 7(1)(2)$ addressing anyone 'comparable' to the person carrying out the environmental damage; see Mähönen 2011, sects. 4.1.1 and 4.1.3.

83. Polish Civil Code Art. 435 CC; see Radwan \& Regucki 2012, sect. 4.2.

84. Federal Bill No. 6938/81 Art. 14(1) and Federal Bill No. 9605/98 Art. 4; see also Art. 50 in Civil Code (general rule of piercing the veil); see Vizziotti, Wendling, Vaz Ferreira \& Quirico 2012, sect. C.1.

85. Ibid., sect. C.1. In such a case, in order to hinder the recovery of damages, it is necessary to prove that there was no deviation from the purpose of the business or confusion of assets between shareholders and the company. The liability of the entity can also be filed as a criminal charge, where Art. 2 Bill No. 9605/98 provides for the responsibility of those who had a duty to act and prevent the commission of a crime: company directors, board members, members of technical agencies, auditors, managers, agents or representatives of a legal entity; cf. Vizziotti, Wendling, Vaz Ferreira \& Quirico 2012, sect. C.2; see also Mähönen 2011, sect. 4.1.3.

86. $\S 7$ (1) (2) of the Act on Compensation for Environmental Damage, referred to in Mähönen 2011, sect. 4.1.3.

87. Mähönen 2011, sect. 4.1.3.

88. Environmental Responsibility Act 26/2007, Art. 10 in conjunction with Art. 42(1) and Art. 18 of the Commercial Code; cf. Escrig-Olmedo et al. 2012, Part C.

89. Swedish Environmental Code (Miljöbalken 1998:808), ch. 10, § 2; see Kløcker Larsen 2014. contrast to the direct environmental liability, the plaintiff will have to provide proof of parental culpability or influence or instruction as a decisive factor for the incurred damage. In Sweden, any legal person that exerts or has exerted a decisive influence on the environment-damaging activity can be held liable and denoted a principle of liability of the 'operator'. ${ }^{90}$ This principle is inspired by EU environmental law, notably the Environmental Liability Directive, that concerns the "powers and duties of public authorities ('administrative approach') as distinct from a civil liability system for 'traditional damage' (damage to property, economic loss, personal injury)" for "pure ecological damage". ${ }^{91}$ Tort creditors may therefore not build their legal claims on this directive since it explicitly states that private parties are not provided "a right of compensation as a consequence of environmental damage or of an imminent threat of such damage". ${ }^{92}$ The purpose of the extended 'operator' approach found in Sweden is to hold the responsible company liable for its deliberate or negligent behaviour in line with the environmental principle of polluter pays, also for private parties. ${ }^{93}$ However, this approach can only lead to parental liability in cases where the parent company itself is to blame.

In contrast to the Swedish 'operator' approach, the US Supreme Court has, in the case of Bestfoods, ${ }^{94}$ explicitly rejected the fact that corporations can be considered as 'operators' in the context of environmental hazardous waste, ${ }^{95}$ leaving veil piercing as the sole option to address the parent company (as the owner of a subsidiary). ${ }^{96}$

\subsection{Main Constraints in the Domestic Statutory Approach}

The two main weaknesses of the domestic statutory liability schemes for environmental externalities are first, the (general) lack of an extraterritorial aspect and second, the narrow focus of intragroup liability providing an unjustified barrier for tort creditors of subsidiaries to address the parent company.

The lack of an extraterritorial aspect is problematic for environmental harm, such as pollution, which might easily have an extraterritorial impact. Further, a foreign parent company will not necessarily be targeted by domestic regulations, as is evident in, for example, the

90. Ebbesson 2006-2007.

91. See <http://ec.europa.eu/environment/legal/liability/> (accessed 19 September 2014). The Environmental Liability Directive (2004/35/CE) Art. 6 defines 'operator' as "any natural or legal, private or public person who operates or controls the occupational activity or, where this is provided for in national legislation, to whom decisive economic power over the technical functioning of such an activity has been delegated, including the holder of a permit or authorization for such an activity or the person registering or notifying such an activity".

92. The Environmental Liability Directive (2004/35/CE), Art. 3(3).

93. Ebbesson 2006-2007, p. 304.

94. The United States v. Bestfoods, 524 U.S. 51 (1997).

95. The US Supreme Court in 1998 where the Court held that a parent corporation could only be held liable as the owner of a subsidiary under ordinary principles of piercing the corporate veil, concerning the US Comprehensive Environmental Response, Compensation and Liability Act ('CERCLA'); see Taylor 2012, sect. 6.4.

96. See Dearborn 2009, p. 236. 
Court of Justice of the European Union's decision in Impacto $\mathrm{Azull} .^{97}$ In this case, the question was whether the exclusion of foreign companies for liability claims in Portugal served as a restriction on the internal market. The Court held that Article 49 TFEU allows national legislation that "excludes the application of the principle of the joint and several liability of parent companies visà-vis the creditors of their subsidiaries to parent companies having their seat in the territory of another Member State", because the parent company can easily contract around this. ${ }^{98}$ In effect, the geographical scope of the Portuguese liability scheme favours creditors with bargaining power against a parent company that can provide them with equal security in an extraterritorial context while leaving tort creditors with potentially no bargaining power at all, with the limitations set forth in a domestic statutory context. ${ }^{99}$ One could say that the decision was not very surprising since the Portuguese legislation explicitly addresses solely Portuguese-affiliated companies. Thereby, an extension to foreign parent companies would be quite far-reaching and questionable as that would allow Portugal to regulate French companies. The latter indicates the need for an EU initiative in this respect and at the same time, that the EU law principle of subsidiarity presumably would be fulfilled in this regard.

A second weakness of some of the domestic statutory regimes is the focus on intragroup compensation, such as in Germany and Portugal, resulting in a limited protection of the subsidiary's creditors. ${ }^{100}$ Further, in certain cases, the creditors are excluded from suing the parent corporation unless the subsidiary is bankrupt. ${ }^{101}$ If the subsidiary is bankrupt and the tort creditor is standing in a lawsuit against the parent company, the burden of proof still reflects a major barrier to succeed redress from the parent, especially when the relevant information concerning the parent's direction of the subsidiary mostly is found within the parent company's offices. This highlights the importance of legal initiatives such as the German integration agreement, the French proposal of a direct liability scheme available for third parties and strict environmental liability for corporate groups.

While there are limited attempts within a domestic statutory context to address parental liability for tort creditors, my next question is whether domestic court has compensated for the legislators' lack of initiative in this respect, by the use of the 'piercing the corporate veil' doctrine.

97. Case C-186/12, Impacto Azul Lda v. BPSA 9 and Bouygues; Rammeloo 2014.

98. Case C-186/12, Impacto Azul, para. 39

99. Even though the Court only answered a precise question of the applicability of the domestic legislation at hand, the legal effect would be that the extraterritorial dimension will exclude the use of the Portuguese liability scheme and that a similar protection of third parties only can be given by the conclusion of a contract between that third party and the company.

100. Singhof 1999, p. 169

101. Ibid., at 169; Alting 1995.

\section{Domestic Judicial Parental Liability: Piercing of the Corporate Veil}

Parental liability can also be imposed by the domestic court. This liability approach is mostly based on variations of the corporate veil doctrine. Corporate veil piercing is a generic term, covering many different realities. ${ }^{102}$ Piercing of the corporate veil is characterized by the courts' ability to make exceptions to the basic rule concerning shareholders' limited liability by disregarding "the separateness of the corporation and hold(ing) a shareholder responsible for the corporation's action as if it were the shareholder's own". ${ }^{103}$ The concept is mostly based on general principles and there is therefore a lack of precise criteria. ${ }^{104}$ Nevertheless, it is based on a formalistic assessment of the parent-subsidiary relationship, where the demonstration of three fundamental elements is often highlighted: the subsidiary's lack of independence; fraudulent, inequitable or wrongful use of the corporate form; and a causal link to the plaintiff's loss. ${ }^{105}$ The criteria have been applied cumulatively, resulting in a restrictive use of the veil piercing doctrine in several jurisdictions. Even though there is a trend towards a more flexible concept of a 'single-factor piercing' as described by Blumberg in the USA, ${ }^{106}$ the dominant understanding of veil piercing still rests on the formalistic assessment of the 'three-factor piercing' described above. ${ }^{107}$

Domestic varieties run from the one end of the spectrum where there is no legal basis for the court to provide judicial piercing such as in Finland, ${ }^{108}$ Iceland, ${ }^{109}$ Norway ${ }^{110}$ and Denmark ${ }^{111}$ to the opposite end, where

102. Vandekerckhove 2007, p. 11. Piercing of the corporate veil can also be regulated in statutory provisions such as in the UK; see, e.g., Dignam \& Lowry 2006, pp. 31-33.

103. Vandekerckhove 2007, p. 1, referring to Thompson 1991, p. 1036.

104. Antunes 1994, p. 486 . The vagueness of the applicability of veil piercing has caused Bainbridge to suggest to abolish the doctrine altogether; cf. Bainbridge 2001, p. 481.

105. Blumberg 2005, p. 612; Blumberg et al. 2005, §§ 11.01 (general), $59.02,60.02$ (torts), 68.02 and 69.01 (contract).

106. Blumberg 2005, p. 612; Blumberg et al. 2005, §§ 12.01 (general), 26.01, 26.02 (jurisdiction), 59.02, 60.01, 60.02 (torts), 68.01 and 69.01 (contract).

107. See, e.g., Strasser \& Blumberg 2009.

108. Mähönen 2011, sect. 8: "It can be pierced if the shareholders act in a disloyal manner towards the company's creditors and abuse the form of incorporation for their own private benefit and at the expense of the creditors".

109. Björgvinsdóttir 2009, p. 51.

110. Sjåfjell 2013, sect. 7.1. In the preparatory works of the Companies Act, there is a reference to the possibility to apply veil piercing in environmental circumstances; see Ot.prp. nr. 55 (2005-2006), p. 125, and in 2013, the Supreme Court held a parent company liable for environmental cleanup after a subsidiary and has been discussed under the framing 'environmental piercing of the veil'; see, e.g., Sjåfjell 2010.

111. Friis Hansen \& Valdemar Krenchel 2010, pp. 139-144; Vinther \& Werlauff 2005, pp. 128-134 
we find jurisdictions like China ${ }^{112}$ and Ghana, where the courts in the latter jurisdiction are left with discretion to pierce "when it is just and in the public interest to do so". 113 The broadness of the latter approach potentially provides a domestic judicial direct liability.

Along the spectrum, we find jurisdictions applying veil piercing under specific circumstances. Such circumstances mostly reflect a causal link between the parent's conduct and the plaintiff's claim, providing an indirect liability scheme enforced by judicial veil piercing. As examples, veil piercing can be justified where companies are regarded as a single economic unit, agency ${ }^{114}$ or facade in the $\mathrm{UK}^{115}$ and India ${ }^{116}$ or as a particular group structure, such as in Germany. ${ }^{117}$

In contrast to the German statutory approach, solely regulating public limited liability companies, parental liability in groups consisting of private limited liability companies is based on a criterion of immediate detrimental financial influence by the parent causing the claim of the creditor. This variation of veil piercing does not take consideration of detrimental parental financial influence over time that can result in, for example, an undercapitalized subsidiary. Thereby, parental liability can only be invoked if the creditor succeeds in providing proof of the parent's abuse of the corporate form (provided by a breach of a duty to guarantee the subsidiary's legal and factual existence based on mandatory capital requirements) as a basis for the creditor's claim. ${ }^{118}$

A problematic aspect of these liability schemes is that the burden of proof lies with the claimants, and in jurisdictions like, for example, the $\mathrm{UK}^{119}$ and Canada, ${ }^{120}$ the claimant will have to successfully prove that the parent

112. Companies Act Art. $20 \mathrm{CL}$; cf. Art. $218 \mathrm{CL}$, referred to in Luo \& Tian 2013, sect. 7.1. The notion of enterprise liability can also be extended to foreign companies investing in Chinese companies, even though the situation with joint ventures is still unclear.

113. Schwartz 2013, sect. 6.3. Pertinent examples are in relation to the fulfilment of certain requirements of the GCC - also s 180(3).

114. Agency situations, described as controlling parent companies that are involved in all (or almost all) of the subsidiary's affairs, leaving the subsidiary to be nothing more than the parent's puppet on a string. A similar approach by the European Court of Justice in competition cases, where the doctrine of veil piercing, as in procedural matters, has been invoked from the early 1970s; see C-48/69 [1972] ECR 619, International Chemical Industries, where the court held that " $[\mathrm{t}]$ he fact that a subsidiary has separate legal personality is not sufficient to exclude the possibility of imputing its conduct to the parent company... in particular where the subsidiary, although having separate legal personality, does not decide independently upon its own conduct on the market, but carries out, in all material respects, the instructions given to it by the parent company".

115. See Adams v. Cape Industries Plc (1990) CH 433. See also Dignam \& Lowry 2006, pp. 33-41.

116. Deva 2011, sect.VII; see also Deva 2012.

117. See cases BGH (17 September 2001 - II ZR 178/99), Bremer Vulkan and BGH (24 June 2002 - II ZR 300/00) and KBV, referred to in ReichGraefe 2005, pp. 800 and 802

118. This represents a shift from the previous judicial doctrinal qualified de facto concern which constituted a direct parental liability for all of the subsidiary's obligations based on a presumption of parental interference without ample respect for the individual interest and autonomy of the subsidiary. For a critical analysis of the German courts' doctrinal reverse, see Reich-Graefe 2005

119. Villiers 2013, sect. 6.1; see, e.g., Adams v. Cape Industries p/c.

120. Richardson 2011, sect. V. exercises such a high degree of control over the subsidiary that the separation is a mere façade or that the subsidiary has "no separate mind, will or existence of its own". ${ }^{121}$ A similar extensive burden of proof can be found in, for example, the US case of Unocal, where the court held that "piercing the corporate veil could not be used to hold parent corporations liable for the torts or human rights abuses of their subsidiaries unless the evidence displayed such unity of interest between the corporate entities that they were functionally the same entity". ${ }^{122}$ Further, the court substantiated a limited applicability of veil piercing by corporations' predictability in this respect, since the use of the doctrine, in the court's opinion, would unacceptably "invalidate the corporate forms commonly employed by a large number of U.S. domestic and international corporations...[and] initiate a sea of change in the way all American corporations do business". ${ }^{123}$

The restrictive application of veil piercing based on an argument of businesses' predictability, rather than focusing on compensation of involuntary creditors, has led to a situation where, and as I will return to below in section 6, "claimants...began to initiate claims against parent companies on the basis that the parent owed them a direct duty of care" instead of struggling within the unpredictability of veil piercing. ${ }^{124}$

The weakness of the domestic judicial approach is the prevalence of entity theory governed by principles of limited liability and recourse to the piercing of the corporate veil. The latter, in turn, without precise criteria, thereby leads to a lack of predictability for the corporate actors and affected parties. ${ }^{125}$ The barrier constituted by the plaintiff's burden of proof for providing evidence of the corporate structure and the intragroup relations leads to an almost illusory path for tort creditors to be compensated by a parent company. By result, the domestic judicial approach only to a limited extent provides a sufficient solution for parental liability for tort claims by third parties.

\section{Extraterritorial Statutory Parental Liability: Pioneering Examples}

National borders pose no barrier to environmental damage. Therefore, there is a need for statutory approaches with the added aspect of extraterritoriality, aiming at regulating the corporate activity regardless of their state of incorporation. An extraterritorial scope can

121. Adams v. Cape Industries plc, cited in Villiers 2013, sect. 6.1; see also e.g. case from British Columbia, International Trademarks Inc. v. Clearly Canadian Beverage Corporation (1999), cited in Richardson 2013, sect. V.

122. Dearborn 2009, p. 197, referring to Doe v. Unocal, para. 31.

123. Ibid., para. 28.

124. Petrin 2013, p. 604

125. See, e.g., Strasser \& Blumberg 2009. 
be achieved in various ways, and I will here describe three different approaches. ${ }^{126}$

An extraterritorial statutory approach can be applied by conflict of law provisions, aiming at clarifying the domestic courts' jurisdiction in international conflicts. In addition to the well-established US Alien Tort Claims Act ${ }^{127}$ where "tort...committed in violation of the law of nations or a treaty of the United States" can be prosecuted by US courts, the Turkish Companies Act provides a similar clarification on the forum "if either of the parent or the subsidiary is resident in Turkey", 128 and the same is valid in the Albanian Companies Act. ${ }^{129}$ In result, the choice-of-law rules indicate that actions by both domestic parent and foreign parent companies that operate in the USA, Turkey or Albania through subsidiaries will be subject to these domestic liability schemes, providing creditors with a legal basis to sue foreign parent companies within the framework of the domestic provisions. ${ }^{130}$ The above-mentioned jurisdictions apply an indirect parental liability scheme in this respect, presuming a direct link between the parent's conduct and the occurred losses.

Within the EU, the Rome II Regulation gives a tort claimant that succeeds in providing proofs of detrimental parental behaviour an extraterritorial statutory right to seek compensation, if the claimant can find a sufficient national scope for parental liability. ${ }^{131}$ Article 7 provides plaintiffs of environmental damage claims a choice of law between (i) lex loci damni (place of the injury) and (ii) lex loci delicti (place of the tortious act). The understanding of the latter was further interpreted in the landmark Bier case ${ }^{132}$ by clarifying that victims of environmental degradation can sue the polluter in home court, place of pollution and the place where the injury was caused.

Another extraterritorial statutory approach can be found in the Albanian Companies Act, where group liability mirrors the recognition of an enterprise. This means that whenever a group is legally accepted, ${ }^{133}$ parallel enterprise liability is established if the parent or a subsidiary is registered in Albania, providing an extraterritorial statutory direct liability scheme. This liability scheme encompasses all of the affiliated companies, not

126. In addition to the approaches mentioned here, choice of law, concept of control and a duty of care, international investment treaties and regulation could presumably also provide some scope of investor liability, but that is beyond the scope of this paper.

127. US Alien Tort Claims Act, 28 USC Sect. 1350 (2000)

128. See Turkish Commercial Code Art. 195; see further Turkish Commercial Code Arts. 195-210; see Eroglu 2013, Part C.

129. In 2008, the Albanian Parliament passed a new Company Law, 'Law No. 9901, dated 14 April 2008 On Entrepreneurs and Companies'. See further Dine 2012.

130. See Turkish Commercial Code Art. 202(e); see further PWC, 'New Turkish Commercial Code: A blueprint for the future', 86-88, available at $<$ www.pwc.com.tr/en_TR/TR/publications/ttk-assets/pages/ttk-a_ blueprint_for_the_future.pdf> (accessed 19 September 2014); Albanian Companies Act Art. 208(4).

131. Rome II Regulation on the Law Applicable to Non-contractual Obligations (EC/864/2007).

132. Bier v. Mines de potassse d'Alsace ECJ 21/76.

133. This depends on whether there is an equity group or control group and the exact moment when the criteria for group structure are met. just the parents' potential liability towards subsidiaries. ${ }^{134}$ In result, anyone (natural or legal person) who can invoke a tort claim is to be regarded as a creditor to the entire corporate group, resulting from their claims, and such a case can then be brought before the Albanian court. ${ }^{135}$

Even though the concept of control as a decisive factor for group liability is somewhat vague and will most probably vary in its application throughout various jurisdictions, we find a common use of the control concept within several US statutory provisions. ${ }^{136}$ The doctrine of control found in the USA was first developed under the 'New Deal' regime in 1933. Control was seen as the predominant enterprise principle, acknowledging the interrelated connection between affiliated companies. As noted by Blumberg, the doctrine "was further strengthened by expansion of the sweep of liability so that it included not only the corporation 'controlling' the corporation violating the statute (the parent corporation) but also the corporations that were 'controlled by' the violator (subsidiaries), as well as corporations that were 'under common control' with the violator (sister subsidiaries and affiliates)."137 In other words, the question of liability rests on the companies related to the violation and thereby a functional rather than a conceptual concept of enterprise accountability and liability.

It is questionable whether US enterprise principles are extraterritorially applicable. It is nevertheless possible that such concepts anchored in domestic statutes can have an extraterritorial reach. An example is the US Foreign Corrupt Practices Act of 1977 that has successfully been applied to foreign subsidiaries of American corporations and is thereby, according to Blumberg, "applied to the full range of multinational abuses such as bribery of foreign officials or illegal political contributions, whether done by American parent corporations or their foreign subsidiaries". ${ }^{138}$

However, the US Supreme Court's decision in Kiobel lays down a restrictive approach on the question of extraterritoriality, when scrutinizing the applicability of the Alien Tort Claims Act, which aims at holding persons and companies liable for wrongdoings abroad. Accordingly, we find that there are examples of variations of extraterritorial statutory approaches, but they can be fragile if a domestic court wishes to narrow its applicability, as we see in the example of Kiobel. Since this case is not in line with previous US practice, we will

134. Dine 2012, pp. 66-67.

135. See Law No. 9901 On Entrepreneurs and Companies Art. 208(4). The identification of group companies in Albanian company law is distinct from, e.g. Belgium, the Netherlands, the UK, the USA, France and Germany, according to Vandekerckhove 2007, p. 534; see also Dine 2012, p. 44.

136. For example, the Bank Holding Company Act, 70 Stat. 133 (1956); 12 U.S.C. § 1841 et seq. (1994); The Savings and Loan Holding Company Act, 12 U.S.C. § 1467(a) (1994); and Gramm-Leach-Bliley Act, Pub. L. No. 106-102, 113 Stat. 1388 (1999) (codified in various sections of titles $12,15,16$ and 18 of the US Code), all referred to by Blumberg 2001, p. 313.

137. Blumberg 2001, p. 313.

138. Ibid., p. 314. 
have to wait for further decisions in order to conclude whether there is a consistent shift in the court's opinion concerning extraterritoriality or whether the Kiobel case is more of a bump in the road.

Finally, there is an interesting new extraterritorial proposal in France, which also addresses parent companies, subsidiaries and supply chains. ${ }^{139}$ The proposed liability scheme builds on a parental duty of care, and liability may arise from business activity that causes harm to the environment or social concerns such as human rights violations. An interesting perspective of the proposal is that:

[The] Presumption of liability is not conclusive and the company may be exempt from liability if it proves that it was not aware of any activity that may have a potential impact on fundamental rights or if it proves that it made every effort to avoid it. ${ }^{140}$

As noted by Taylor, this is in reality a due diligence provision, providing for due diligence as a defence and thereby shifting the burden of proof from the tort creditors and onto the companies. ${ }^{141}$ Due diligence procedure is familiar within the context of international soft law mechanisms such as the UN Guiding Principles and the OECD Guidelines for Multinational Enterprises. The inclusion of these existing legal mechanisms into statutory provisions with extraterritorial reach is a potential successful path for the domestic legislatures to fill the regulatory gap of group liability. It still remains to be seen whether this extraterritorial parental liability scheme will be adopted. However, it serves as an interesting proposition to bridge the definition of responsibility for business activity with the international standard of due diligence as enforcement mechanism, in order to provide an extraterritorial solution to the global concern of group liability.

The examples mentioned reflect the possibility of including the aspect of extraterritoriality either by choice-of-law provisions in company law, by an enhanced recognition of the doctrine of control or by a factual understanding of responsibility of the business activity as a whole - regardless of national borders. However, the solution offered by the choice-of-law mechanism in Albania and Turkey could be seen as having a negative impact on company registration, resulting in being perceived as less favourable jurisdictions within which to register an affiliated company. This emphasizes the importance of a proper understanding of multinationals as interlinked, controlled units, where the appropriate liability scheme should focus neither on national affiliated companies nor on a formalistic assessment of registration or shareholdings. The French proposal for legislation can be an example to follow, by its factual understanding of responsibility based on business activity. Further, the proposed shift of burden of proof in France by due diligence as a defence can serve

139. See Taylor 2014, pp. 86-89.

140. Prop. de Loi 1524, 11, translated by Taylor 2014, p. 86.

141. See Taylor 2014. as an important mechanism to operationalize an extraterritorial group liability scheme.

\section{Extraterritorial Judicial Parental Liability: Foreign Direct Liability and Parental Duty of Care}

Conflict rules provide a choice of law based on the legal classification of the occurred event, and this can vary across jurisdictions. Company law and tort law, for example, can provide the claimants with different results. In jurisdictions applying a restrictive veil piercing approach or inefficient statutory regulations, the claimants could benefit from trying to file the case as a matter of tort by a breach of a parental duty of care, ${ }^{142}$ instead of arguing within the unpredictability of company law principles occasionally justifying veil piercing. This is the basis for the extraterritorial judicial approach and the evolving legal trend of 'foreign direct liability' (FDL) cases. In these cases, claimants have filed tort claims against a foreign parent company, in their home jurisdiction, for the environmental or human rights offences caused by the local subsidiary. In other words, and regardless of its characterization as a 'direct liability', an FDL case is an example of an extraterritorial judicial indirect parental liability, holding the foreign parent company liable for its own wrongdoings (breach of a duty of care). ${ }^{143}$

Two cumulative criteria have to be met in order to file an FDL case: First, an alleged violation of (written or unwritten) norms pertaining to proper societal conduct as reflected in a duty of care. Second, the parent has to be directly involved in the violation and thus has to have a degree of control over the acts of the subsidiary that would justify liability. ${ }^{144}$ In the UK decision, Chandler v. Cape plc, the Court of Appeal further elaborated these two cumulative criteria into a new four-part test for ascertaining a parental duty of care for health and safety of individuals employed by a group company: ${ }^{145}$

1. The business of the parent and subsidiary is in a relevant respect the same;

142. A fiduciary duty of care is usually imposed on directors in their running of a company. The concept in a parental context reflects that the parent owes a duty of care towards affected parties of a subsidiary's conduct and can be held liable for a breach of this duty - most often by negligence of such duty; see, e.g., reasoning in Chandler v. Cape plc (UK, 2012) EWCA Civ 525.

143. Meeran 2011. In international law, the distinction between indirect and direct liability used in a corporate context usually reflects a state liability as an expression of an indirect liability approach and a corporate liability as an expression of a direct liability scheme. In the current context, these cases are identified by the influence or negligence of the parent company and thereby, qualify as an indirect liability scheme.

144. Enneking 2012, p. 175.

145. Chandler v. Cape p/c (2012) EWCA Civ 525, at para. 40 stating that "it appears that there is no reported case of a direct duty of care on the part of a parent company". 
2. The parent has, or ought to have, superior knowledge on some relevant aspects of health and safety in the particular industry;

3. The subsidiary's system of work is unsafe as the parent company knew or ought to have known; and

4. The parent knew or ought to have foreseen that the subsidiary or its employees would rely on its using that superior knowledge for the employees' protection. ${ }^{146}$

The basic premise for applying the four-part test is a requirement of 'relevant control' in the parent-subsidiary relationship. The court failed to define the proper meaning of the term 'relevant control'. However, by reference to Connelly v. RTZ Corp plc, ${ }^{147}$ the court held that "there is nothing in either judgment or in the general law to support the submission...that the duty of care can...only exist if the parent company has absolute control of the subsidiary". ${ }^{148}$ By the court's reasoning, the parameters of parental influence and involvement in the subsidiary's business seem to be the two key elements in the concept of parental control, which, in turn, represent an assumption of responsibility that is necessary for proximity demanded by a duty of care analysis. ${ }^{149}$

However, the vague concept of 'relevant control' results in uncertainty, and as noted by Petrin, it can be invoked whenever the parent company has intervened in a subsidiary's operations, leaving parent companies potentially liable "even when there is no nexus between the parent's involvement and the harm that a claimant suffered". ${ }^{150}$ From the perspective of the claimants, this approach could provide a basis of an extraterritorial judicial direct parental liability if maintained by the courts. A wide interpretation of Chandler in conjunction with, for example, Lubbe v. Cape plc ${ }^{151}$ paints a picture of a potential broad parental liability exposure, where both individual employees of group companies and nonemployee third parties can invoke a parental duty of care, assuming the parent's "relevant control of the subsidiary's business". ${ }^{152}$ The court's broader way of reasoning facilitates the factual aspect of an enterprise with its closely interlinked economic relationships and also provides room for fulfilment of the underlying interests and policies involved. However, the willingness to disregard the corporate privileges lacks consistency. This is evident from the contrast between the outcomes in the cases of Adams v. Cape plc and Lubbe v. Cape plc. Even though both cases on the face of it concern the same underlying claim of parental duty of care towards its subsidiaries' employees, the Court of Appeal did not lift the veil in Adams, but did so in the Lubbe case with ref-

146. Chandler v. Cape plc, para. 80.

147. Connelly v. RTZ Corp plc (1999) CLC 533.

148. Chandler v. Cape p/c, para. 66

149. Petrin 2013, pp. 610-612.

150. Ibid., 613.

151. Lubbe v. Cape plc (2000) 1 WLR 1545. The case consisted of more than 5000 claimants - both employees and nonemployee local residents for health issues related to their work in a South African asbestos mine.

152. Chandler v. Cape plc, para. 46 erence to an underdeveloped court system in the country of the subsidiary, and the parent company could thereby be sued in the UK for its subsidiary's actions. ${ }^{153}$ A broad recognition of group liability in hazardous tort claims can be found in, for example, India, in the rare case of M.C. Mehta v. Shriram Food and Fertilizer Industries, where the Court in 1987 adopted an absolute standard of extraterritorial direct judicial parental liability:

[A]n enterprise...engaged in a hazardous or inherently dangerous industry...owes an absolute and nondelegable duty to the community that no harm results to any one on account of the dangerous nature of the activity it has undertaken...If the enterprise is permitted to carry on the hazardous or inherently dangerous activity for its profit, the law must presume that such permission is conditional on the enterprise absorbing the cost of any accident. ${ }^{154}$

Many of the FDL cases are settled in out-of-court agreements, missing a determinative opportunity to hold a foreign parent accountable for the tortious behaviour of its subsidiaries. ${ }^{155}$ One of the reasons for out-ofcourt settlements in these cases is probably the overall constraints related to FDL claims. These are the questions of jurisdiction, of choice of law and of statutory provisions in environmental and corporate law as well as procedural questions. ${ }^{156}$ Additionally, there are national varieties that presumably will lead to a lack of predictability. There can, for example, be differences in the court's willingness to accept cases where the connection with the forum can be questioned, jurisdictions applying forum non conveniens dismissing cases based on its relation to the jurisdiction of the court, ${ }^{157}$ and also the differences in domestic legislative approaches towards parental extraterritorial liability. As an example of the former, UK courts seem quite open-minded in terms of hearing cases with an extraterritorial aspect. This is evident in, e.g. Chandler v. Cape plc and ${ }^{158}$ Petrodel $v$. Prest ${ }^{159}$ and most recently in Pike and Doyle v. Indian Hotel Companies Ltd. ${ }^{160}$ In the latter, the UK court elaborates on the questions of jurisdiction, concluding that it was "clearly the case that England is the appropriate forum for the trial" based on "the interests of all the

153. Dignam \& Lowry 2006, p. 45.

154. A.I.R. 1987 S.C. 1086, referred to in Baxi 1999, pp. 400-401.

155. See, e.g., BHP Billiton case in Australia, aiming at holding an Australian parent company liable for environmental pollution caused by Ok Tedi Mine operated by its subsidiary in Papua New Guinea; cf. Kirsch 1996. It is alleged that in 1995, BHP drafted a bill for the PNG parliament that proposed fines of up to $\$ 75,000$ on anyone who filed proceedings against BHP in courts; Imhof 1996.

156. Enneking 2012, Ch. 4

157. Barrett Jr. 1947. Within the EU, the Court has clarified that forum non conveniens is not permitted under the Brussels I regime, also covering cases involving non-member states; see C-281/02 Owusu v. Jackson et al.

158. Chandler v. Cape p/c (UK, 2012) EWCA Civ 525.

159. Petrodel v. Prest (2012) UKSC 34.

160. Pike and Doyle v. Indian Hotel Companies Ltd (2013) EWHC 4096 (QB). 
parties and the ends of justice". ${ }^{161}$ This broad approach and willingness to hear cases with extraterritoriality seem to be in contrast to the recent decision by the US Supreme Court in Kiobel - albeit that this case was based on the statutory regulations in ATCA and not tort law principles as in the foreign direct liability cases. ${ }^{162}$

Regardless of the constraints, the significance of tort claims in this regard is the use of different parameters to address liability than those found within corporate law. ${ }^{163}$ As a result, the courts have created a possibility to explore a potential extension of parental liability, even though there are several obstacles to overcome in order to successfully be compensated by the foreign parent. ${ }^{164}$ Despite these obstacles, Zerk optimistically predicted a bright future for extraterritorial parental liability (before the Kiobel case), represented by the:

Sharp increase in the number of 'foreign direct liability' claims' including 'a number of prominent home states (...)' e.g. 'the UK, the USA, Australia and Canada', and that several factors can provide further FDL litigation, such as high profile of CSR, media interest and the 'financial and procedural advantages offered by many of these home state courts over foreign ("host state") alternatives (such as contingency fee representation or the possibility of class actions)' 165

Foreign direct liability has been identified as an evolving legal trend, and the increasing willingness of national courts to try these cases provides room for a potential new liability scheme that perhaps will facilitate a factual recognition of the activities of corporate groups.

\section{Summary and Future Prospects}

The significance of corporate groups is evolving, with increasing economic and political power. Limited liability of shareholders as a feature of the modern corporation was never created to protect control and opportunism. Multinational groups are expanding and entering into new markets using the advantages provided by the corporate privileges of separate legal personality and limited liability. Corporate and economic development should, however, be mirrored in satisfactory liability schemes, especially for involuntarily creditors. There are plenty of suggestions of how to shift over to a liabili-

161. Ibid., para. 71

162. Kiobel v. Royal Dutch Petroleum Co., 133 S. Ct. 1659 - Supreme Court 2013.

163. For specific environmental damages, there are already a number of international treaties enforceable.

164. As examples, I can mention the high costs, difficulties for the courts that in some cases would have to apply foreign tort law, procedural difficulties based on the extraterritorial aspect of these cases, the fact that few lawyers have competence, etc.

165. Zerk 2006, pp. 198-199 ty scheme that reflects the gain of corporate groups, on the one hand, and their liabilities on the other.

In order to hold a foreign parent liable for its subsidiaries' externalities, one must be able to bypass the corporate privileges of separate legal entity and limited liability and also find a basis for the claim in the applicable choice of law. With the Albanian and Turkish Companies Acts as rare pioneering examples, and the French solution only a proposal, we are mostly left with judicial piercing in the extraterritorial context. Judicial piercing, leaving domestic courts with varying degrees of discretion and most often legitimated through a company's shareholding, does not provide sufficient predictability to address parental liability.

There is a need for a functional rather than a conceptual approach in this respect, where all elements of corporate groups are brought together in order to evaluate its operations and liability. The concept of 'control' can provide us with a key in this regard. Strasser and Blumberg have proposed a modern enterprise theory where a factual concept of group recognition is merged with the underlying policies and purposes of the legislation at hand. The application of the modern enterprise theory in cases of, e.g., environmental degradation would provide courts with discretion to scrutinize the purpose of the invoked environmental legislation and thereby potentially conclude parental liability based on proper fulfilment of the legislation at hand. Thereby, the theory bypasses the notion of separate legal entities and limited liability aiming at fulfilling, e.g. compensation purposes found in environmental law. Nevertheless, this would only happen if the factual relationship between the parent and subsidiary is closely interlinked and they function as an integrated economic unit. In that case, parental liability could be a possibility.

Furthermore, the foreign direct liability cases brought before the courts reveal an evolving willingness, also within common law jurisdictions, to apply a broader factual notion of the enterprise, rather than a strict application of the entity theory. However, the burden of proof left with the claimants in these cases will most likely result in a barrier to successfully address parent companies. Therefore, one could suggest a shift in the burden of proof, like in the French proposal, leaving the parent company to "bring evidence as to whether the challenged decisions [or occurred environmental damage] have originated from its control or were taken autonomously by the subsidiaries". ${ }^{166}$ Antunes calls this shift in burden of proof a 'floating and flexible' liability scheme, which is targeted to compensate for the difficulties the burden of proof can represent for the claimants. ${ }^{167} \mathrm{~A}$ shift in the burden of proof could presumably narrow the effect of the corporate privilege of limited liability, leaving the parent with liability if sufficient evidence is not provided indicating otherwise. This could be offered through due diligence procedures and there-

166. Antunes 1994, pp. 132, 384 and 493 et seq.; Vandekerckhove 2007, pp. 544-545.

167. Antunes 1994, pp. 132, 384 and 493 et seq. 
by also facilitates an enterprise theory where consideration of the interests involved can be dealt with in advance and not solely in retrospect through liability schemes. ${ }^{168}$ Still, there are too many uncertainties and constraints to sufficiently address parental liability, especially in an extraterritorial context. This indicates a need for legislative reform at an international level, where important mechanisms such as a basic rule of parental burden of proof for externalities of subsidiaries are one of the key features.

Groups were the preferred corporate structure already in the 1920s and 1930s. Berle called for a theory of group liability for mass torts, human rights violations and environmental harm in the 1940s; Blumberg, amongst others, questioned the lack of group regulations in the 1980s, and still, in 2015, there is a lack of a functional group liability scheme based on recognition of the economic reality of a parent-subsidiary relationship. It may therefore be suggested that legislative action is long overdue.

\section{Bibliography}

J.E. Antunes, Liability of Corporate Groups: Autonomy and Control in Parent-Subsidiary Relationships in U.S., German and EEC Law: An International and Comparative Perspective, Deventer/ Boston, Kluwer Law and Taxation Publishers 1994.

J.E. Antunes, The Law of Corporate Groups in Portugal, Johann Wolfgang Goethe Universitat, Institute for Law and Finance Working Paper Series No. 84 05/2008, 2008.

T. Bachner, E.P. Schuster \& M. Winner, The New Albanian Company Lam. Interpreted According to Its Sources in European Law, Tirana, Guttenberg 2009.

U. Baxi, Mass Torts, Multinational Enterprise Liability and Private International Lam, Martinus Nijhoff Publishers 1999.

Y. Biondi et al., The Firm as an Entity: Implications for Economics, Accounting, and the Law, Routledge 2007.

P. Blumberg, The Lam of Corporate Groups. Tort, Contract and Other Common Lam Problems in the Substantive Lam of Parent and Subsidiary Corporations, Gaithersburg, New York, Aspen Law \& Business 1987 and 2000.

P. Blumberg et al., Blumberg on Corporate Groups, Aspen Publishers, 2nd edition, 2005.

A. Dignam \& J. Lowry, Company Lam, Oxford University Press 2006.

L. Enneking, Foreign Direct Liability and Beyond: Exploring the Role of Tort Lam in Promoting International Corporate Social Responsibility and Accountability, Eleven Law 2012.

S. Friis Hansen \& J. Valdemar Krenchel, Dansk selskabsret 1, Thomson Reuters, 3rd edn, 2010.

Y. Guyon, "The Law on Groups of Companies in France", in E. Wymeersch (ed.), Groups of Companies in the EEC, de Gruyter 1993, pp. 140-163.

T. Hadden, The Control of Corporate Groups, Institute of Advanced Legal Studies, University of London 1983.

168. See, e.g., criteria in Chandler v. Cape for parental burden of proof which could also be used as a due diligence mechanism. See also Taylor 2014. This could also be achieved if the proposal presented by Beate Sjåfjell, for including into the duties of the board a life-cycle-based integration of environmental and social aspects of the value creation the entity's business is based on, is followed up on; see Sjåfjell 2015.
D.T. Hamilton, "Regulation of Corporations under International Environmental Law", Proceedings of the Annual Conference of the Canadian Council of International Law 1989, pp. 72-92.

J. Mähönen \& C. Villiers, "Accounting and Reporting Standards”, in B. Sjåfjell \& B.J.Richardson (eds.), Company Law and Sustainability, Cambridge University Press, forthcoming 2015.

P.J. Nikolicza, "Hungary: Corporate Governance of Listed Companies", in A.M. Fleckner \& K. Hopt (eds.), Comparative Company Law, Cambridge University Press 2013, pp. 572-603.

C. Redgwell, "International Environmental Law", in M.D. Evans (ed.), International Lam, Oxford University Press, 4th edn, 2014, pp. 688-726.

P. Sands et al., Principles of International Environmenal Lam, Cambridge University Press 2012.

H. Schneider \& M. Heidenhain, The German Stock Corporation Act: Bilingual Edition with an Introduction to the Lam, The Hague: Kluwer Law International, München, C.H. Beck, 2nd edn, 2000.

B. Sjåfjell, "Corporate Governance for Sustainability. The Necessary Reform of EU Company Law", in B. Sjåfjell \& A. Wiesbrock (eds.), The Greening of European Business under EU Law, Routledge, forthcoming 2015.

K. Vandekerckhove, Piercing the Corporate Veil: A Transnational Approach, Kluwer 2007.

N. Vinther \& E. Werlauff, Dansk og international koncernret og koncernskatteret, Forlaget Thomson 2005.

E. Werlauff, "The Debtor behind the Debtor, the Tortfeasor behind the Tortfeasor. On Liability for Another Company's Default and Other Debts", 5 European Company Law 5, 2008, pp. 207-219.

G. Wirth \& M. Arnold, Corporate Law in Germany, C.H. Beck 2004.

J. Zerk, Multinationals and Corporate Social Responsibility, Cambridge University Press 2006.

\section{Articles in Journals:}

C. Alting, "Piercing the Corporate Veil in American and German Law - Liabilities of Individuals and Entities: A Comparative View", 2 Tulsa Fournal of Comparative and International Lam 2, 1995, pp. 187-251.

S. Bainbridge, "Abolishing Veil Piercing", 26 Fournal of Corporate Law, 2001, pp. 479-535.

E.L. Barrett Jr., "The Doctrine of Forum Non Conveniens", 35 California Lam Reviem 3, 1947, pp. 380-422.

A.A. Berle, "The Theory of Enterprise Entity", 47 Columbia Lam Reviem, 1947, pp. 343-358.

Y. Biondi, "The Problem of Social Income: The Entity View of the Cathedral", 34 Seattle University Lam Reviem 4, 2011, pp. $1025-1047$.

Y. Biondi, "The Governance and Disclosure of the Firm as an Enterprise Entity", 36 Seattle University Lam Reviem 2, 2013, pp. 391-416.

Y. Biondi, "Better Accounting for Corporate Shareholding and Environmental Protection", 11 European Company Lam 2, 2014, pp. 129-132.

Á. Björgvinsdóttir, "Icelandic Company Law", Stockholm Institute for Scandinavian Law 1957-2009, 2009, pp. 45-66. Available at <www.scandinavianlaw.se/pdf/45-3.pdf> (accessed 3 June 2014).

P. Blumberg, "Accountability of Multinational Corporations: The Barriers Presented by Concepts of the Corporate Juridical 
Entity", 24 Hastings International and Comparative Lam Reviem, 2001, pp. 297-320.

P. Blumberg, "The Transformation of Modern Corporation Law: The Law of Corporate Groups", 37 Connecticut Lam Reviem 3, 2005, pp. 605-618.

J.M. Buchanan \& W.M. Craig Stubblebine, "Externality", 29 Economica, 1962, pp. 371-384. Available at <doi: 10.2307/2551386> (accessed 2 September 2014).

J.L. Černič, "Corporate Responsibility for Human Rights: A Critical Analysis of the OECD Guidelines for Multinational Enterprises", 4 Hanse Lam Reviem 1, 2008, pp. 71-101. Available at <http://ssrn.com/abstract $=1317263>$ (accessed 2 June 2014).

M. Dearborn, "Enterprise Liability: Reviewing and Revitalizing Liability for Corporate Groups", 97 California Lam Reviem 1, 2009, pp. 195-261.

S. Deva, "Sustainable Business and Australian Corporate Law: An Exploration", University of Oslo Faculty of Law Research Paper No. 2013-11, 2013. Available at <http://ssrn.com/ abstract $=2248621>($ accessed 2 February 2014).

S. Deva, "Socially Responsible Business in India: Has the Elephant Finally Woken Up to the Tunes of International Trends?", 41 Common Law World Reviem 4, 2012, pp. 299-321. Available at <http://ssrn.com/abstract $=2084576>$ (accessed 12 June 2014).

S. Deva, "Sustainable Business and Indian Company Law: A Critical Review", Draft mapping paper on file with author, 2011.

J. Dine, "Jurisdictional Arbitrage by Multinational Companies: A National Law Solution?", 3 fournal of Human Rights and the Environment 1, 2012, pp. 44-69.

F.H. Easterbrook \& D.R. Fischel, "Limited Liability and the Corporation”, 52 University of Chicago Law Reviem, 1985, pp. 89-117.

J. Ebbesson, “Ansvar i Sverige för miljöskadlig verksamhet utomlands”, $\mathscr{F}$ T, 2006-2007, pp. 279-310.

M. Eroglu, "Obstacles and Possibilities for Sustainable Companies in Turkey", University of Oslo Faculty of Law Research Paper No. 2013-04, 2013. Available at <http://ssrn.com/ abstract $=2218220>$ (accessed 2 february 2014).

E. Escrig-Olmedo et al., "Sustainable Companies. Spanish Mapping Paper on Company Law Issues", University of Oslo Faculty of Law Research Paper No. 2012-36, 2012. Available at $<$ http://ssrn.com/abstract=2181337> (accessed 2 February 2014).

T. Hadden, "Inside Corporate Groups", 12 International fournal of the Sociology of Lam, 1984, pp. 271-286.

H. Hansmann \& R. Kraakman, "Towards Unlimited Shareholder Liability for Corporate Torts", 100 Yale Law Fournal 7, 1991, pp. 1879-1934.

J.J. Henning, A. du Plessis \& A. Koorsen, "Sustainable Companies, Climate Change and Corporate Social Responsibility in South African Law”, Draft mapping paper on file with author, 2012.

A. Imhof, "The Big, Ugly Australian Goes to Ok Tedi”, $17 \mathrm{Mul}$ tinational Monitor 3, 1996. Available at <http:// multinationalmonitor.org/hyper/mm0396.05.html> (accessed 29 September 2014).

A. Johnston, "Governing Externalities: The Potential of Reflexive Corporate Social Responsibility", Centre for Business Research, University of Cambridge, Working Paper No. 436, 2012. Available at <http://ssrn.com/abstract $=2165616 \mathrm{Z}>$ (accessed 4 July 2014).

S. Kirsch, "Cleaning up Ok Tedi: Settlement Favors Yonggom People", 4 Journal of the International Institute 1, 1996. Available at <http://hdl.handle.net/2027/spo.4750978.0004.104> (accessed 29 September 2014).
R. Kløcker Larsen, "Foreign Direct Liability Claims in Sweden: Learning from Arica Victims KB v. Boliden Mineral AB?", 4 Nordic Fournal of International Lam, 2014.

E. Lauraityte \& P. Miliauskas, "Sustainable Companies under the Lithuanian Company Law", University of Oslo Faculty of Lam Research Paper No. 2013-10, 2013. Available at <http://ssrn. $\mathrm{com} /$ abstract $=2248591>($ accessed 2 February 2014).

J. Lou \& L. Tian, "A Study on Sustainable Companies in the P. R. China”, University of Oslo Faculty of Law Research Paper No. 2013-05, 2013. Available at <http://ssrn.com/abstract= 2218284> (accessed 2 February 2014).

J. Mähönen, "Sustainable Companies mapping paper on company law issues: Finland", Draft mapping paper on file with author, 2011.

R. Meeran, "Tort Litigation against Multinational Corporations for Violation of Human Rights: An Overview of the Position Outside the United States", 3 City University of Hong Kong Law Reviem 1, 2011, pp. 1-41.

D. Millon, "Piercing the Corporate Veil, Financial Responsibility, and the Limits of Limited Liability", 56 Emory Lam Fournal 5, 2007, pp. 1306-1382.

M. Petrin, "Assumption of Responsibility in Corporate Groups: Chandler v Cape plc", 76 The Modern Lam Reviem 3, 2013, pp. 603-619.

A. Radwan \& T. Regucki, "The Possibilities for and Barriers to Sustainable Companies in Polish Company Law", International and Comparative Corporate Lam Fournal, University of Oslo Faculty of Law Research Paper No. 2012-32, 2012. Available at $<$ http://ssrn.com/abstract $=2159217>$ (accessed 3 January 2014).

S. Rammeloo, "The Judgment in CJEU C-186/12 (Impacto $A z u l)$ : Company Law, Parental Liability and Article 49 TfEU - A Plea for a 'Soft Law' Oriented EU Law Approach on Company Groups", 11 European Company Law 1, 2014, pp. 20-29.

R. Reich-Graefe, "Changing Paradigms: The Liability of Corporate Groups in Germany", 37 Connecticut Law Reviem, 2005, pp. 785-818.

B.J. Richardson, "Canadian Company Law: Barriers and Possibilities for Sustainable Companies", Draft mapping paper on file with author, 2011.

C. Schmitthoff, "Banco Ambrosiano and Modern Company Law”, Fournal of Business Lam, 1982.

P. Schwartz, "Developing States and Climate Change: Solutions in Company Law?", University of Oslo Faculty of Law Research Paper No. 2013-15, 2013. Available at <http://ssrn. $\mathrm{com} /$ abstract $=2275177>($ accessed 31 January 2014).

B. Singhof, "Equity Holders' Liability for Limited Liabilities Companies' Unrecoverable Debts - Reflections on Piercing the Corporate Veil under German Law", 22 Loyola of Los Angeles International and Comparative Lam Reviem, 1999, pp. 143-174.

B. Sjåfjell, "Internalizing Externalities in EU Law: Why Neither Corporate Governance nor Corporate Social Responsibility Provides the Answers", 40 George Washington International Lam Reviem 4, 2009, pp. 977-1024. Available at <http://ssrn. com/abstract $=1139584>$ (accessed 20 April 2014).

B. Sjåfjell, "Sustainable Companies: Possibilities and Barriers in Norwegian Company Law", University of Oslo Faculty of Law Research Paper No. 2013-20, 2013. Available at <http://ssrn. $\mathrm{com} / \mathrm{abstract}=2311433>($ accessed 29 September 2014).

B. Sjåfjell, "Environmental Piercing of the Corporate Veil: The Norwegian Supreme Court Decision in the Hempel Case", 7 European Company Law, 2010, pp. 154-160. Available at $<$ http://ssrn.com/abstract $=1616820>$ (accessed 24 September 2014). 
J. Stamenkova van Rumpt, "Macedonia: Mapping Paper on the Company Law Barriers and Possibilities for Sustainable Companies", Draft mapping paper on file with author, 2011.

K. Strasser \& P. Blumberg, "Legal Models and Business Realities of Enterprise Groups - Mismatch and Change", CLPE Research Paper No. 18/2009, 2009. Available at <http://ssrn. com/abstract $=1440858>$ (accessed 12 February 2014).

K. Strasser \& P. Blumberg, "Legal Form and Economic Substance of Enterprise Groups: Implications for Legal Policy", 1 Accounting, Economics and Law - A Convivium 1, 2011, pp. 1-28.

K. Strasser, "Piercing the Veil in Corporate Groups", 37 Connecticut Law Reviem, 2005, pp. 637-665.

C.R. Taylor, "United States Company Law as it Impacts Corporate Environmental Behavior, with Emphasis on Climate Change", International and Comparative Corporate Law Journal (Forthcoming), University of Oslo Faculty of Law Research Paper No. 2012-31. Available at <http://ssrn.com/ abstract $=2159659>($ accessed 10 March 2014) .

M.B. Taylor, "Due Diligence: A Compliance Standard for Responsible European Companies", 11 European Company Law 2, 2014, pp. 86-89.

R.B. Thompson, "Piercing the Corporate Veil: An Empirical Study", 76 Cornell Lam Reviem, 1991, pp. 1036-1074.

C. Villiers, "Mapping Paper: Sustainable CompaniesUK Report", Research Paper No. 2013-16, University of Oslo Faculty of Law, 2013, available at <http://ssrn.com/ abstract $=2280350>($ accessed 10.February 2015).

V. Vizziotti et al., "Sustainable Companies under Brazilian Regulation: A Substantive and Procedural Overview", Draft mapping paper on file with author, 2012.

J. Zrilič, "Mapping Paper on the Barriers and Possibilities for Integrating Environmental Sustainability into Slovenian Company Law”, Draft mapping paper on file with author, 2012. 